\title{
Cattle population dynamics in the southern Ethiopian rangelands, 1980-97
}

\author{
SOLOMON DESTA AND D. LAYNE COPPOCK
}

Authors are former Graduate Research Assistant and Associate Professor, Department of Rangeland Resources, Utah State University, Logan, Utah 843225230. Desta has continued as a Post-Doctoral Associate in the same department based in East Africa. The correspondence co-author is Coppock.

\begin{abstract}
Knowledge of livestock population dynamics is important to better understand functional attributes and development potential of pastoral production systems. With a focus on the Borana system of semi-arid Ethiopia for 1980-97, the main objectives of this research were to: (1) Characterize cattle population trends; (2) determine associations of rainfall and stocking rate with change in cattle numbers; and (3) estimate economic losses from cattle mortality. We predicted that the regional cattle population trend would consist of a "boom and bust" cycle with long periods of gradual herd growth punctuated by drought-induced losses. We expected that cattle losses would occur when high stocking rates were combined with large rainfall deficits. Such observations would refute the idea that cattle numbers were erratic and purely controlled by rainfall variation, as predicted by non-equilibrium theory. Cattle dynamics were quantified using herd histories from interviews of 56 households living in 4 sites. Data were aggregated to portray regional cattle population trends and quantify economic losses. Regression analysis was employed to assess associations of rainfall variation and stocking rate with cattle dynamics using 2 approaches: (1) Regional using aggregate herd data, empirical rainfall records, and calculated estimates for stocking rates; and (2) local using site-specific herd data along with recall of rainfall and stocking rate dynamics. Overall, results confirmed that cattle numbers followed a boom and bust cycle. Average cattle holdings dropped from 92 to 58 head/household between 1980 and 1997, respectively. Droughts in 1983-5 and 1991-3 resulted in the deaths of 37 to $42 \%$ of all cattle, respectively, up to 15-times higher than net sales. Over 17 years our target population of 7,000 households lost 700,000 cattle with a capital asset loss valued at USD 45 million. Statistical results were more difficult to interpret. Our regional approach indicated neither rainfall nor stocking rate were significantly associated with cattle mortality. We felt this interpretation was erroneous, however, due to a probable-but unmeasured-decline in key
\end{abstract}

Financial support for this work was provided by Utah State University (USU), the Rockefeller Foundation, the International Livestock Research Institute (ILRI), and the Small Ruminant/Global Livestock Collaborative Research Support Program of the United States Agency for International Development under the terms of grant no. DAN-1382-G-00-0046-00 and no. PCE-G-98-00036-00.

Susan Durham (USU) and Ato Zerihun Tadesse (ILRI) are acknowledged for assistance with statistics and sampling design, respectively. Dr. Simeon Ehui and other staff at ILRI are thanked for their guidance and support. Mulugeta Shibru, Seyoum Tezera, Godana Wario, and Mohammed Ibrahim assisted with field data collection. Comments from anonymous reviewers helped us improve the manuscript.

This paper is dedicated to the memory of Dr. James E. Ellis and his many important contributions to the study of African pastoral ecosystems.

Manuscript accepted 11 Nov. 01. grazing resources that lowered carrying capacity, increased herd instability between successive droughts, and undermined relationships among model parameters. Our local approach was somewhat clearer in that results indicated cattle losses were significantly and consistently associated with rainfall deficits, and occasionally associated with high stocking rates that varied by site. We were concerned, however, about respondent bias and possible error in these results. We concluded that the strongest information we had was simply the aggregate pattern of herd dynamics. When aligned with empirical rainfall records and augmented with data from another dramatic cattle crash in 1998-9, we make the case that stocking rate indeed appears to influence the likelihood that a dry year will reduce cattle numbers. We concluded that the Boran live in a dynamic and productive equilibrial system where land-use change has interacted with rainfall variation to create a vicious cycle of massive cattle losses every 5 to 6 years. Improving human welfare under such circumstances should focus on creating a virtuous cycle based on more timely livestock sales, alternative investment of revenues, and sustainable economic diversification.

Key Words: Borana, pastoralism, drought, equilibrial/non-equilibrial systems, risk management

\section{Resumen}

El conocimiento de las dinámicas de la población del ganado es importante para un mejor entendimiento de los atributos funcionales y el desarrollo de sistemas de producción pastoriles potenciales. Enfocados en el sistema Borana de la región semiárida de Etiopía durante el período de 1980-1997, los principales objetivos de esta investigación fueron: (1) caracterizar las tendencias de la población de ganado bovino, (2) determinar las asociaciones de la precipitación y las cargas animal con el cambio en el número de ganado y (3) estimar las perdidas económicas debidas a la mortalidad de ganado. Predijimos que la tendencia de la población regional de ganado consistiría en un ciclo de aumento y caídas rápidas con largos períodos de crecimiento gradual del hato puntualizado por perdidas inducidas por sequía. Esperábamos que las perdidas de ganado ocurrirían cuando se combinaban altas cargas animal y grandes déficit de lluvia. Tales observaciones refutarían la idea de que los números de cabezas de ganado bovino eran erráticos y puramente controladas por la variación de la precipitación, tal como lo predice la teoría de no-equilibrio. Las dinámicas de ganado bovino se cuantificaron usando los historiales de los hatos de 56 ganaderos entrevistados que viven en 4 sitios. Los datos se agregaron para describir la tendencia regional de la población de ganado y cuantificar Las perdidas económicas. Se emplearon análisis de regre- 
sión para evaluar las asociaciones de las variaciones de precipitación y la carga animal con las dinámicas del ganado mediante el uso de metodologías: (1) Regional, usando los datos agregados de los hatos, registros empíricos de precipitación y cargas animal calculadas y (2) local, usando los datos específicos del hato por sitio en conjunto con la dinámica de registros de precipitación y carga animal. Los resultados generales confirman que el número de cabezas de ganado bovino siguió un ciclo de aumento y caída rápida. Entre 1980 y 1998 el tamaño de hato promedio cayó de 92 a 58 cabezas/propietario respectivamente. Las sequías de 1983-1985 y 19911993 resultaron en muertes del 37 al $42 \%$ de todo el ganado respectivamente, hasta 15 veces más que las ventas netas. A lo largo de 17 años nuestra población objetivo de 7,000 propietarios perdió 700,000 cabezas de ganado, con perdidas estimadas en \$ 45 millones de dólares americanos. Los resultados estadísticos fueron más difíciles de interpretar. El método regional indico que ni la precipitación ni la carga animal estuvieron asociadas significativamente con la mortalidad del ganado. Sentimos que esta interpretación fue errónea, sin embargo, debido a una probable, pero no cuantificada, disminución en los recursos clave del apacentamiento que bajaron la capacidad de carga animal, incrementaron la inestabilidad del hato entre sequías sucesivas y una relación indeterminada entre los parámetros del modelo. Nuestra metodología local fue algo más clara respecto a que los resultados indicaron que las perdidas de ganado fueron significativamente $y$ consistentemente asociadas con los déficit de precipitación y ocasionalmente asociados con altas cargas animal que variaron por sitio. Sin embargo, estuvimos preocupados respecto a los sesgos de los entrevistados y el posible error en estos resultados. Concluimos que la información más firme que tuvimos fue simplemente el patrón agregado de la dinámica del hato. Cuando uniformizamos los datos empíricos de precipitación y aumentamos los datos con otra caída dramática de ganado en 1998-1999, concluimos que de hecho la carga animal parece influenciar la probabilidad de que un año seco reducirá el número de ganado. Concluimos que el Boran vive en un sistema en equilibrio dinámico y productivo donde el uso de la tierra ha interactuado con la variación de la precipitación para crear un ciclo vicioso de perdidas masivas de ganado cada 5 o 6 años. El mejoramiento del bienestar humano bajo tales condiciones debe enfocarse en crear un ciclo virtuoso basado en ventas de ganado más oportunas, inversiones alternativas y la diversificación económica sustentable.
Two models have been forwarded to characterize the ecology of pastoral system dynamics in East Africa. An "equilibrial" model has been proposed whereby herbivores reach population densities at which they exert negative, density-dependent feedback on their own productive performance and degrade or alter natural resources (Lamprey 1983). A "non-equilibrial" model, in contrast, has been proposed whereby climate (i.e., rainfall) variability plays the supreme role in keeping herbivore numbers below a density at which they could negatively affect themselves or influence the environment (Ellis and Swift 1988). The 2 models fundamentally differ in the presumed importance of biotic versus abiotic controls over ecosystem processes. The models consequently vary in the utility of concepts such as ecological carrying capacity, defined as the population density at which there is no net change in secondary production (Caughley 1979). While the concept of ecological carrying capacity is a foundation for managing herbivores and vegetation in equilibrial systems, it can be viewed as irrelevant in non-equilibrial systems (Ellis and Swift 1988, Ellis et al. 1993, Behnke and Scoones 1993).

Coppock (1993) and Dodd (1994) postulated that both equilibrial and non-equilibrial systems occur in Africa, with the former predominating in semi-arid zones and the latter in arid zones. A key factor in whether rainfall variability could control herbivore populations is drought frequency, and drought frequency-along with annual variability in rainfall - tends to increase with aridity (Ellis et al. 1993). A higher frequency of drought reduces the chance that herbivore numbers will steadily grow and increases the chance that the forage base will be dominated by unstable annuals adapted to aridity - a potential problem for the population stability of grazing animals (Coppock 1993).

Coppock $(1993,1994)$ hypothesized that the Borana pastoral system of semi-arid Ethiopia is primarily shaped by equilibrial dynamics. Observations in the region during the 1980s suggested that cattle production was affected by chronic interactions between stocking rate and annual rainfall, while another consequence of heavy grazing pressure was localized bush encroachment and soil erosion (Coppock 1993, 1994).

The main objectives of this research were to: (1) Characterize cattle population trends for the period 1980-97; (2) deter- mine associations of rainfall and stocking rate with annual change in cattle numbers; and (3) estimate economic losses from cattle mortality. This approach would allow us to better categorize this production system as equilibrial or non-equilibrial from the herbivore perspective and provide an empirical test of theory. The third objective was part of a risk management assessment. Results were expected to have important implications for pastoral development strategy and policy.

\section{Materials and Methods}

\section{Study Area}

The Borana Plateau $\left(95,000 \mathrm{~km}^{2}\right)$ is in southern Ethiopia at an elevation of 1,000 to $1,500 \mathrm{~m}$. The northern border of the plateau is about $600 \mathrm{~km}$ south of the capital city of Addis Ababa. The plateau extends south to the Kenya border, west to the Rift Valley, and east towards the Ogaden plains.

The regional climate is semi-arid and supports a mixed savanna dominated by perennial grasses (Cenchrus, Pennisetum, Chrysopogon spp.) and woody plants (Acacia, Commiphora spp.). Annual rainfall in the north-central portion of the plateau-where this work was conducted-typically averages 550 to $700 \mathrm{~mm}$, with $60 \%$ received during the long rains from March to May and 30\% during the short rains from September to November. A cool dry season occurs from June to August, while a warm dry season occurs from December to February.

The dominant ethnic group is the Boran, who currently number about 325,000 and herd over 1 million head of cattle along with much smaller numbers of sheep, goats, and camels (J. Helland, unpubl.; S. Desta, unpubl.). The Borana production system has been described in detail by Cossins and Upton (1987) and Coppock (1994), but a few points concerning resource use and system dynamics are repeated here. Livestock can range widely in search of forage and water during dry periods, but households in general are increasingly settled for most of the year. Households occur in encampments that are commonly located within $30 \mathrm{~km}$ of towns and markets. Cattle are managed as either home-based warra herds dominated by milch cows and calves, or more far-ranging forra herds dominated by bulls, dry cows, and hardy immatures. Resource use 
in the central portion of the plateau is based on a traditional system where about 30 communities (madda) are loosely organized with respect to permanent systems of deep wells and associated grazing areas. Human labor required to lift water from deep wells in dry periods has led to an unusually high degree of social cohesion and cooperation in resource use among the Boran compared to many other pastoral societies. Communities located outside of this central portion of the plateau, however, have more heterogeneous forms of social organization and resource use, primarily because dry-season water in these locales is supplied more by ephemeral streams and shallow wells that do not require the same degree of organized labor.

Productivity of forage and livestock is seasonally dynamic, with flushes of primary and secondary production associated with rainy periods. Dry periods, in contrast, are times when green forage and drinking water become scarce, animals lose weight, and people reduce food intake. The traditional diet of the Boran is based on milk from livestock, but this is increasingly supplemented with purchased and home-grown cereals (often maize) as the human population expands and the ratio of cattle to people declines. Grazing lands are becoming more limited as a result of woody encroachment, cultivation, and neighboring ethnic groups crowding the landscape. Food insecurity is an increasing problem (Desta 1999).

Cattle sales are typically low, reflecting a modest need for cash income. Although some animals enter market channels heading north to the Ethiopian highlands, the vast majority of cattle are sold to Kenyan interests that offer higher prices. The cross-border trade has a large black-market component and accurate numbers for these transactions are lacking (Coppock 1994).

Aspects of the development policy environment for pastoralists in Ethiopia are reviewed in Coppock (1994), Desta (1999), and by J. Moris (unpubl.) A few key points will be summarized here.

Pastoral development policy in Ethiopia is not easy to discern - it can change when the national or local government changes, implementation varies by region, and policy is rarely explicit in official documents. It is evident, however, that pastoral people in general have never been a priority for the national government. Indeed, pastoralists tend to be politically marginalized throughout much of the Greater Horn of
Africa when compared to the influences of highlanders and cultivators.

Based on our observations in Ethiopia over the past 15 years, we surmise that the main development goals for the Borana Plateau have included: (1) Promotion of a commercial cattle trade for domestic and formal export markets; (2) maintenance of security; and (3) protection of natural resources, especially endangered wildlife and remnant patches of forest at higher elevations. Large multilateral investments were made in physical infrastructure (roads, livestock market facilities, etc.) and delivery of livestock health services in the southern rangelands during the 1970s and 1980s, and this was intended to set the stage for increased livestock sales by pastoralists. While the physical access to market has increased for the Boran compared to 30 years ago, there is little other evidence that the multilateral investments have directly led to marked improvements in pastoral livelihoods.

Scant resources in the public sector have precluded any broad-based delivery of basic human services (education, health, transportation, etc.) to pastoralists. Literacy rates remain low $(<10 \%)$ and numerous human health problems remain unchallenged. The Boran therefore still appear to largely fend for themselves and manage their own internal affairs, but under a broad umbrella of government supervision.

Livestock marketing has been a dynamic area for policy intervention. During a period of socialist rule from 1977 to 1991 , government interference in livestock and grain markets was pervasive throughout the nation. The Boran were compelled to sell cattle to the state at below-market prices to supply export quotas and provide beef for a large military. Since 1991 the new regime eliminated livestock sales quotas and price controls, and beef prices subsequently increased. Both governments have tried to control illicit cross-border flows of livestock in the hope of recovering more tax revenue, but success has been limited because the borders are difficult to seal off.

Changes in natural resources and land use have occurred on the Borana Plateau in recent years, but these issues have not yet received much attention from policy makers or land-use planners. Local officials and pastoralists express concern about perceived degradation of natural resources in forms such as bush encroachment and soil erosion. Many Boran have also noted concern with the recent proliferation of locally controlled forage preserves and farming plots that effectively privatize land previously used under rules of common access. These types of problems are thought to ultimately be due to pressure from a growing human population, which in turn has encouraged heavier stocking rates and opportunistic cultivation to meet increased demand for milk and grain production. Importantly, with respect to the main focus of this paper, to our knowledge there has never been a forced, officially sanctioned, de-stocking of pastoral herds on the Borana Plateau in the name of range management, although pastoralists have taken the initiative to implement their own controlled grazing schemes in a few madda. Projects to rehabilitate deep wells or create ephemeral ponds have been pursued with caution to reduce the chance for resource degradation associated with water points. A general ban on range fires has been enforced for about 25 years, with an eye towards protecting natural resources from alleged toofrequent burning. This has precluded the traditional use of fire by the Boran for range management and tick control that occurred for centuries. Finally, activities such as charcoal making, unregulated harvest of timber for urban home construction, use of rare trees for rural handicraft production, or harvest of key wildlife species are illegal or otherwise discouraged. Hunting occurs, however, as firearms remain abundant in the system. Possession of firearms by the Boran has been officially sanctioned for many years as one means to encourage a vigilant militia near potentially sensitive international borders.

\section{Predictions and Hypotheses}

Although a full assessment of system dynamics should ideally include vegetation as well as herbivores, our focus in this study was confined to the cattle component. This was primarily because our main research objective dealt with risk management, and this required assessment of animal assets at the household level of resolution (Desta 1999). Cattle comprise about $90 \%$ of livestock biomass on the central Borana Plateau and thus were the ideal species to investigate because of their dominance. The environment is also relatively favorable in terms of animal health and a general lack of livestock rustling. Net sales of animals out of the system are also quite limited. Cattle herd dynamics, 
therefore, are largely determined by the interactions of animals with forage supplies (Coppock 1994).

We wanted to determine the degree to which cattle dynamics have been influenced by stocking rate (equilibrial) and/or rainfall (non-equilibrial) events. Both situations offer distinct predictions.

For a non-equilibrial system, Ellis and Swift (1988) and Ellis et al. (1993) noted that the pattern of livestock dynamics should be density independent, "abiotically driven," and "volatile" in nature. They did not offer an empirical example of livestock dynamics from their study region of arid Turkana District, Kenya, but rather created long-term (65-year) patterns for livestock body condition using a simulation model that portrayed animal nutritional status as a function of forage quantity and quality dynamics (Ellis et al. 1993). Body condition was therefore used as a proxy for other production responses such as lactation, natality, and mortality (M. Coughenour and J. Ellis, pers. comm.). This work suggested that in a non-equilibrium setting, livestock populations should be less able to closely track a highly variable carrying capacity.

For an equilibrial system opposite patterns should hold, namely that population dynamics should be dominated by densitydependent interactions, appear as limit cycles, and exhibit more stability than volatility. This would provide evidence that a livestock population is able to at least intermittently track carrying capacity (Ellis and Swift 1988).

For the semi-arid Borana system, our expectation was that the overall pattern of cattle dynamics over 17 years would reveal a mix of equilibrial and non-equilibrial controls, but tend to be dominated by the former. Specifically, we anticipated that we would confirm a "boom and bust" pattern of herd growth where relatively long periods of herd expansion would be punctuated by sharp, drought-induced crashes. A boom and bust pattern for pastoral livestock dynamics has been observed elsewhere in semi-arid Kenya (Meadows and White 1979, Homewood and Lewis 1987) and wetter areas of semiarid Zimbabwe (Scoones 1993).

For our research we relied on empirical methods that focused on the determination of cattle mortality as a function of stocking rate and annual rainfall. The selection of cattle mortality as the key response variable is justified in the next section.

If the Borana system is dominated by non-equilibrial phenomena, an analysis of the effects of rainfall and stocking rate on cattle mortality should reveal that rainfall is most important. In other words, compared to effects of high stocking rates, low rainfall should cause more mortality. Our prediction, however, was that cattle mortality would be affected by both high stocking rate and low rainfall. In particular, we anticipated that the interaction between stocking rate and rainfall would be critical in explaining the dramatic crashes in cattle numbers that have occurred in recent years. We felt that the regional herd would be most vulnerable to drought-induced mortality if stocking rates were high.

We used 2 general analytical approaches in our research. Both approaches relied on cattle mortality data collected from interviews of pastoral households located across 4 study sites, and this is described more fully in the next section. The 2 approaches were somewhat complimentary because they operated at different spatial scales and posed different analytical challenges.

In the first approach we aggregated cattle data across all 56 households to create a pattern of cattle dynamics for the regional herd. We then assessed annual change in regional cattle numbers as a function of regional annual rainfall from official records and regional stocking rates that we estimated using various assumptions. We refer to this as the regional approach. A regional scale of resolution was justified because, particularly during times of drought stress, cattle can move among madda in pursuit of forage and water. Social relationships among residents of different madda influence reciprocal patterns of resource access (Coppock 1994).

In the second approach we kept the analysis at a local level of resolution (within madda) and analyzed cattle mortality across the 4 sites as a function of changes in local rainfall and local stocking rates as recalled by our Borana respondents. We refer to this as the local approach.

Finally, we wanted to make general estimates for the economic consequences of cattle mortality in this system. We expected that cumulative economic losses over many years in a boom and bust cycle could be very high-possibly in tens of millions of USD. Like other traditionally minded pastoralists, the Boran tend to hold cattle for household milk production and as capital assets rather than as a source of marketable products to generate a steady income stream (Coppock 1994). Hence, the Boran tend to postpone cattle sales during droughts until they have no choice-initial sales usually coincide with a sudden need to buy large amounts of human food (grain), and this happens after the cows have ceased to lactate. This can occur 6 months to even a year after a long drought is underway. This collective behavior that resists capital asset depletion under stress can have disastrous consequences, because by the time cattle are marketed the body condition is poor and the numbers are too large to be readily absorbed by marketing channels. Cattle prices therefore collapse compared to the pre-drought situation, and an accompanying drop in the terms-of-trade of livestock for grain contributes to famine risk (Coppock 1994).

\section{Sampling}

The target population for this research was comprised of about 7,000 pastoral households residing within a $35-\mathrm{km}$ radius of the towns of Arero, Mega, Negelle, and Yabello in the north-central region of the plateau. These towns tend to occur at higher elevations having more rainfall than the surrounding areas. Population sizes for the towns ranged from 4,100 (Arero) to 5,240 (Mega), 10,300 (Yabello), and 25,000 (Negelle) based on data in CSA (1996). Distance between towns varies from about $50 \mathrm{~km}$ (Yabello to Arero) to $100 \mathrm{~km}$ (Mega to Negelle). Urban and peri-urban households typically pursue non-pastoral livelihoods as traders, farmers, etc., and were not considered part of our target population, however. This resulted in "doughnut-shaped" sampling zones with urban and peri-urban populations omitted in the center. The cumulative $15,500-\mathrm{km}^{2}$ area that we sampled represented $16 \%$ of the Borana Plateau in terms of size and contained about $15 \%$ of the Borana pastoral population (Desta 1999).

The 4 town-based sampling areas are henceforth referred to here as study sites. Study sites varied with respect to rainfall, production systems, and natural resource management (Desta 1999). The Negelle and Arero sites have higher annual rainfall compared to that for Yabello and Mega. The Yabello and Arero sites have more pressure on grazing land from expanding cultivation. The Mega site has the least problems of the 4 sites concerning possible competition between grazing and culti- 
vation because the lower rainfall and thinner soils at Mega precludes most farming. The Mega site also has the least potential problems of the 4 with regards to grazing disputes with neighboring ethnic groups, simply because Mega is located in the middle of Borana territory. The Borana traditional form of grazing control based on dry-season access to water in permanent deep-wells (the madda system) is most evident in Mega. People in the Yabelo and Arero sites access dry-season water from deep-wells, ephemeral wells, and permanent ponds. People in the Negelle area obtain water more from ephemeral wells and seasonal surface flows. Of all sites, grazing control appears most loosely structured at Negelle. Overall, grazing resources appeared most limiting in relation to population density for the Yabello and Arero sites, hence the expansion of cultivation.

A sampling frame was created by listing all households in the 4 study sites, given there was no official census for us to use. Our list was created using interviews of government officials and pastoral leaders who resided in the scores of villages and encampments that occurred throughout the study sites. The process of creating the sampling frame took 6 months.

Once the sampling frame was completed, key informants were used to help stratify households according to wealth class [i.e., "wealthy," "middle class" or "poor" based on modal ratios of cattle per person of $14: 1,7: 1$, and $2: 1$ respectively (Assefa 1990)]. Our sampling design was thus stratified random, blocked by site. Characterization of the target population revealed that $7 \%$ of households were wealthy, $37 \%$ were middle class, and $56 \%$ were poor (Desta 1999). The wealthy owned $28 \%$ of the cattle, while the middle class and poor owned 46 and $26 \%$, respectively. We sampled wealth classes in equal numbers and not in proportion with their occurrence, however. We felt that sampling an equal number of households per wealth class would improve the accuracy and comparability of parameter estimates. Calculation of overall means for the target population involved weighting statistics according to the relative abundance of each wealth class.

A sample of 336 households (or $4.8 \%$ of the target population) was selected for interview concerning their perceptions of change in the pastoral system, and this work is reported elsewhere (Desta 1999). A sub-sample of 60 randomly selected households, however, was identified for a detailed analysis of cattle herd dynamics reported in this paper. These households were stratified with 15 per site ( 5 per wealth class per site). The smaller subsample of 60 was selected because the detailed interviews would require more time and effort for each sample unit.

\section{Data Collection and Statistics Interview Method}

Data on cattle population dynamics were collected using interviews that focused on recollections of pastoral households. Such approaches have been shown to be effective with African pastoralists because these people place a very high cultural value on livestock and have welldeveloped mental skills to track animal inventories (Assefa 1990, Ensminger 1992). A lack of official statistics for cattle populations in this region also required we use this method.

Fifty-six out of the 60 households identified for detailed interviews were successfully located and agreed to participate. The interviews were held with entire extended families covering 2 to 3 generations and took up to 2 days to complete for each household. Respondents were not informed of our predictions to reduce the chance they would tell us what they thought we wanted to hear. Families were asked to form consensus and recall herd histories from 1997 to 1980 in a stepwise fashion. The 17-year period was needed to capture 2 droughts in 1983-5 and 1991-3. The Borana traditional calendar (Legesse 1973) was used along with known benchmark years for droughts and other ecological, social, political, and cultural phenomena to help respondents organize their thoughts. Annual estimates of the household herd size, recruitment, mortality rates, and net sales were obtained. Mortality was also segregated with respect to mature cattle and immature cattle $<4$ years old, as the latter are more vulnerable to drought, disease, accidents, and predation (Coppock 1994).

\section{Regional Approach for Cattle Dynamics}

For the regional approach we wanted to analyze the association of change in current annual rainfall ( $\Delta R F)$ and previous years' stocking rate (SR) with current annual change in cattle numbers $(\triangle \mathrm{CAT}$ TLE) at a regional scale. The logic was that a major increase in current annual rainfall from the previous year could stimulate herd growth, while a major decrease in current annual rainfall compared to the previous year could lead to more cattle deaths and increased sales leading to a net reduction in herd size. Stocking rate in the previous year would be an indicator of potential resource pressure in the current year. A higher stocking rate in the previous year, for example, could imply that key resources would be rapidly consumed in the current year, especially if forage production was low due to insufficient rainfall. We felt this was the most resolution these data sets could provide. We used a multiple linear-regression model (SAS Institute 1996) that incorporated main effects of $\triangle R F$ and $S R$ as well as an interaction term $(\triangle R F \times S R)$ on $\triangle C A T$ TLE. Current annual change in cattle numbers was calculated based on total head of cattle averaged across the 56 households for each year. Annual change in rainfall was calculated from empirical data (above) averaged across the 4 study sites in each year. Stocking rates were estimated based on the average number of cattle per household per year (our data) and by invoking a series of assumptions that allowed us to back-calculate numbers of total households and hence estimate total head of cattle from the benchmark of 1997. These assumptions included that: (1) Households had an average of 6.5 people throughout the 17 years, as estimated from data in Assefa (1990), Coppock (1994), and Desta (1999); and (2) human population growth was $2.2 \%$ per annum (CSA 1996). This resulted in a time series that began with 4,947 households and 32,154 head of cattle in 1980 and ended at 7,007 households and 45,546 head of cattle in 1997 (D. Coppock, unpubl.). Our ability to make legitimate comparisons of stocking rates over time also required us to assume that: (1) The size of the regional grazing area stayed roughly the same over 17 years; and (2) the ecological attributes of similar stocking rates did not change over time. In other words, under similar levels of rainfall, a stocking rate of 20 head $/ \mathrm{km}^{2}$ yielded the same degree of resource pressure in the early 1980s as it did in the mid-1990s. This last assumption may have been the weakest of all, as surveys on pastoral perceptions of production system trends indicated that the people felt that the regional carrying capacity was declining (Desta 1999; see Study Area). Despite such perceptions, however, we had no reasonable means to prove that carrying capacity had indeed declined. 


\section{Local Approach for Cattle Mortality}

For the local approach we wanted to analyze associations of current annual rainfall $(\mathrm{RF})$ and local stocking rate (SR) with cattle mortality (M). In contrast to the regional approach, however, we based this local approach entirely on interview data. In the process of reconstructing herd histories we also asked respondents to recall annual levels for RF and SR on a 5-point, ordinal scale [i.e., very high (5), high (4), average (3), low (2), or very low (1)]. While there was no means to validate recollections for local SR, we could validate recollections for $\mathrm{RF}$ using empirical rainfall records. A correlation between empirical data and perceived rainfall levels over 17 years was performed using the nonparametric Spearman's test (SAS Institute 1996).

Reliance on mortality as a primary indicator of herd dynamics has positive and negative aspects. The negative aspect is that mortality is a relatively less sensitive indicator of stocking rate pressure than, say, milk production, weight gain, or even calving rates. The positive aspect, however, is that mortality should be a more objective indicator given our data would be founded on people's recollections. We therefore expected mortality dynamics to provide a reasonable test of predictions. We confined our interview questions to only a few aspects of cattle dynamics - avoiding other details on yearly aspects of cattle production and recruitment, for example - because we did not want respondents to suffer from interview fatigue.

Preliminary inspection of the data indicated that the overall pattern for cattle mortality tended to be episodic. There were extended periods when little or no mortality occurred, but these were punctuated by high-mortality events. We therefore used a 2-stage analysis to determine: (1) The degree to which perceived levels of RF, SR, and the RF x SR interaction were associated with mortality events; and (2) associations of the same factors with the magnitude of mortality once it occurred. It would not be surprising, for example, if a drop in annual rainfall was the factor most strongly associated with triggering mortality events, and a higher stocking rate was the factor most strongly associated with magnitude of death loss once a shock was initiated. The 2-stage analysis also helped us circumvent statistical problems related to meeting normality assumptions for statistical procedures due to a large number of zero-mortality values in the full data set.
The first analysis was based on 176 to 193 observations per cattle age class per site and employed a multiple logistic regression in a doubly repeated-measures design. The repeated-measures variables were household and year and these were both modeled as random effects. The dependent variable was binary, i.e., whether or not cattle mortality occurred for any given household in any given year. A normal-error model is not appropriate for binary response, so a generalized mixed model (Littell et al. 1996) was fit using the GLIMMIX macro in SAS Release 6.12 (SAS Institute 1996) that specified binomial errors and a logit link.

The second analysis also employed a multiple logistic regression in a doubly repeated-measures design. In this case, however, we only used from 41 to 103 observations per cattle age class per site for all instances when mortality differed from zero. Percent mortality was calculated based on household herd size in any given year, and these figures were weighted by the household herd size for more accurate population estimates. Percent mortality was successfully transformed to meet assumptions of normality and homogeneity of variance using the natural log of the angular transformation (Afifi and Clark 1990). A general, linear model was fit using PROC MIXED in SAS Release 6.12 (SAS Institute 1996).

In both analyses data were analyzed separately for each of the 4 study sites because each differed in terms of resource attributes (Desta 1999). Data were also segregated with respect to whether cattle were mature or immature.

\section{Economic Value of Cattle Losses}

Our secondary objective, namely estimating the economic value of cattle mortality losses over the 17 years, was performed using mortality data classified by sex, age class, and year. We then multiplied the numbers of animals that died times the respective cattle prices in local currency (Ethiopian Birr). Unpublished records of cattle prices were available from the Southern Rangelands Development Unit (SORDU; a local government agency) and CARE, a non-governmental organization that deals with relief and development. Official rates of currency exchange were USD $1.00=2.07 \mathrm{Birr}$ (1980-90) or 5.50 Birr (1991-97). The shift in currency value was associated with a change in government and implementa- tion of a devaluation policy (Desta 1999). Economic losses per household and per person were estimated on the basis of a target population of 7,007 households and 7.3 people per household for 1997 (Desta 1999).

\section{Results}

\section{Rainfall}

Considered over 17 years and across the 4 study sites, the mean annual rainfall from the climate monitoring stations was $706 \mathrm{~mm}$ with a coefficient of variation (CV) of $25 \%$. This mean was probably biased high compared to the conditions experienced by most of our target population. This is because the monitoring stations are located in the towns, towns are located at higher elevations (as previously mentioned), and rainfall increases with elevation here (Coppock 1994). We considered, however, that the general chronological pattern for rainfall-averaged across the 4 sites - to be a reasonable depiction of the overall situation (Fig. 1).

\section{Regional Cattle Dynamics General Patterns and Magnitude of Economic Losses}

Cattle population dynamics averaged across the 56 households are shown in Figure 2. Two things are apparent, namely a long-term decline in average cattle holdings per household and a pattern of gradual herd growth punctuated by sharp declines. Cattle holdings fell from an average of 92 to $58 \mathrm{head} /$ household in 1980 and 1997, respectively, a net drop of $37 \%$ overall. The sharp declines in inventory were reportedly due to mortality, not sales. Death losses were typically 10 to 15 -times higher than net sales (Fig. 2). The net loss of cattle in the mid-1980s was 34 head/household, or $37 \%$. The average household herd then recovered to $85 \%$ of the previous peak size by 1990 . The subsequent loss of cattle in the early 1990s was $33 \mathrm{head} / \mathrm{household}$ or a decline of $42 \%$. The plunges in cattle numbers in the mid-1980s and early 1990 s were thus similar in scope and appear to be associated with declines in annual precipitation, although the decline in precipitation observed during the mid-1980s was greater than that during the early 1990 s (Figs. 1, 2). Respondents indicated that the vast majority of cattle deaths were due to malnutrition and starvation, with only a 


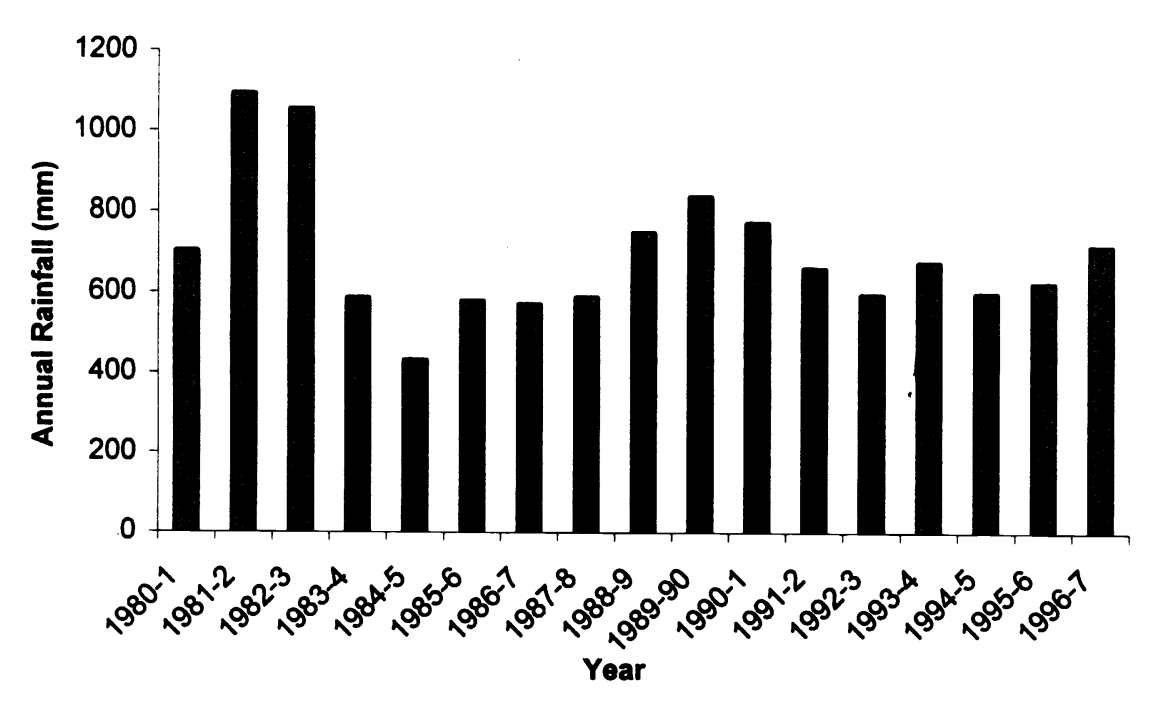

Fig. 1. Annual rainfall for the north-central Borana Plateau, 1980-97, as averaged across 4 meterological stations at Arero, Mega, Negelle, and Yabello. Data source: Ethiopian National Meterological Organization (unpubl.).

few due to disease, predation, or other factors (Desta 1999).

Cattle population dynamics for the 3 wealth classes are shown in Figure 3. The average cattle holdings for wealthy, middle-class, and poor households declined from 171,55 , and 40 head in 1980 , respectively, to 129,42 , and 16 head by 1997. This represented a net drop of around $25 \%$ for the wealthy and middleclass and $60 \%$ for the poor.

The average, cumulative loss of cattle due to mortality over 17 years was 327 , 107 , and 65 head for wealthy, middleclass, and poor households, respectively. This translated into an average economic loss for wealthier households of USD 21,000 , followed by USD 6,880 and USD

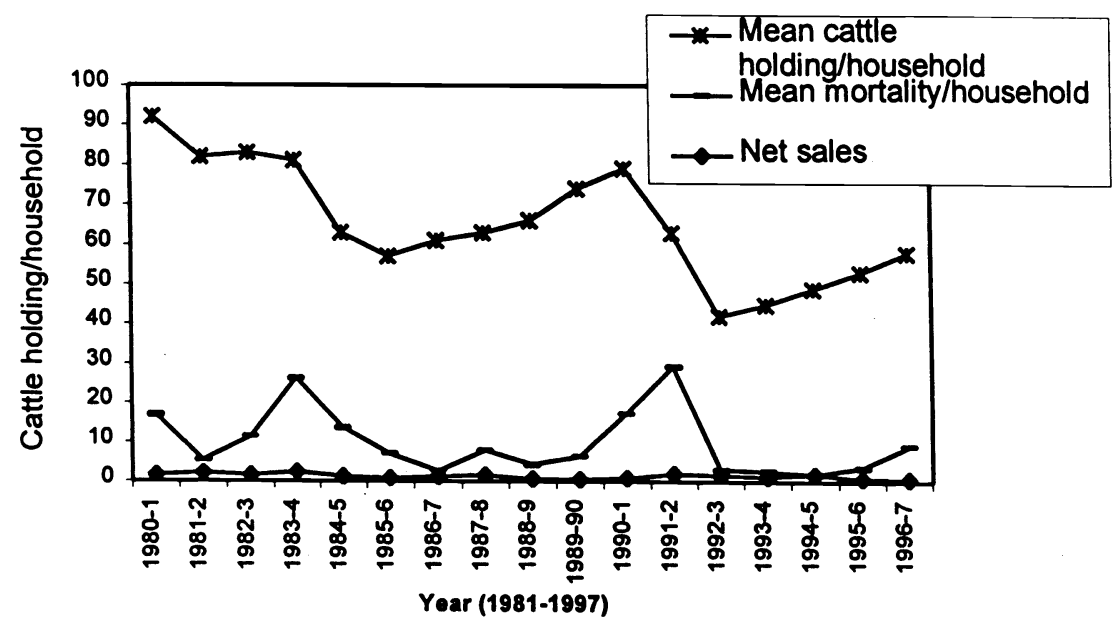

Fig. 2. Cattle population dynamics (average number of head/household) aggregated across 56 Borana households for the period 1980-97 and broken-out according to total, total mortality, and net sales. Source: Desta (1999). vious years' stocking rate $(\mathrm{SR} ; \mathrm{P}=0.15)$, or the $\triangle \mathrm{RF} x \mathrm{SR}$ interaction $(\mathrm{P}=0.74)$.

Data used in this analysis, along with ancillary comments, are shown in Table 1. If we assume the data sets are fundamentally valid and have been properly aligned, it is difficult to discern why neither change in rainfall or stocking rate had significant effects on cattle numbers given the primary sources of mortality given by respondents. One possible explanation, however, is that over time the system was changing in ways that undermined the utility of the statistical analysis. For example, our results could have occurred because of a progressive loss or degradation of drought grazing-reserves (key resources) between 1985 and 1991 (Table 1). Survey respondents have often mentioned that the accessibility and utility of drought grazingreserves has been compromised by overpopulation, bush encroachment, and renewed tensions along ethnic borders (Coppock 1994, Desta 1999). We therefore speculate that diminished grazingreserves have contributed to a greater instability of the regional cattle herd in response to drought perturbation, as evidenced by the lagged pattern of cattle losses in 1983-5 compared to the abrupt crash for 1991-3 (Table 1). It is also notable that the cumulative deviation in annual rainfall, as compared to the 15-year mean, was -316 $\mathrm{mm}$ in 1983-5, yet only $-66 \mathrm{~mm}$ in 1991-3 (Table 1). The system thus appears to have been more buffered in response to a greater rainfall shock in the first drought compared to what transpired in the second drought.

If there has been a significant and progressive loss of grazing reserves, it has several unfortunate implications for the validity of the multiple regression. First, it implies that resource pressure from similar stocking rates has grown more intense over time, undermining the analytical utility of our SR variable. Second, a qualitatively different response of the cattle population to each drought markedly reduced the chance for a significant $\triangle \mathrm{RF} \times \mathrm{SR}$ interaction given the relatively short length of time for which data were collected given research objectives (S. Durham, pers. comm.).

\section{Local Cattle Mortality Perceptions of Rainfall Levels and Stocking Rates}

There was a high degree of agreement between the actual occurrence of drought years and the recall of survey respondents. 
For example, 87 and $75 \%$ of households, respectively, independently identified the drought periods of 1983-5 and 1991-3 as times of low rainfall and hardship. Results from the Spearman's correlation analysis, however, indicated that perceived rainfall levels were not significantly correlated with actual rainfall $\left(\mathrm{r}_{\mathrm{s}}=0.18, \mathrm{P}=0.49\right)$. For stocking rates, survey respondents were fairly consistent within any given study site in their recollection of local stocking-rate levels. Overall, a tally of responses showed that stocking-rate levels were perceived to gradually increase during the inter-drought periods of 1985-90 and 1993-7 (S. Desta, unpubl.).

\section{Associations of Rainfall and Stocking Rate with Cattle Mortality}

Results from the statistical analysis of factors associated with the occurrence of cattle mortality over the 17 years are shown in Table 2 . These results indicate that mortality events were significantly and often strongly associated with decreased rainfall in each site for both age classes of cattle. Mortality events were significantly associated with increased stocking rates for all cases except mature cattle in the Mega and Negelle sites. Despite the prevalence of main effects for

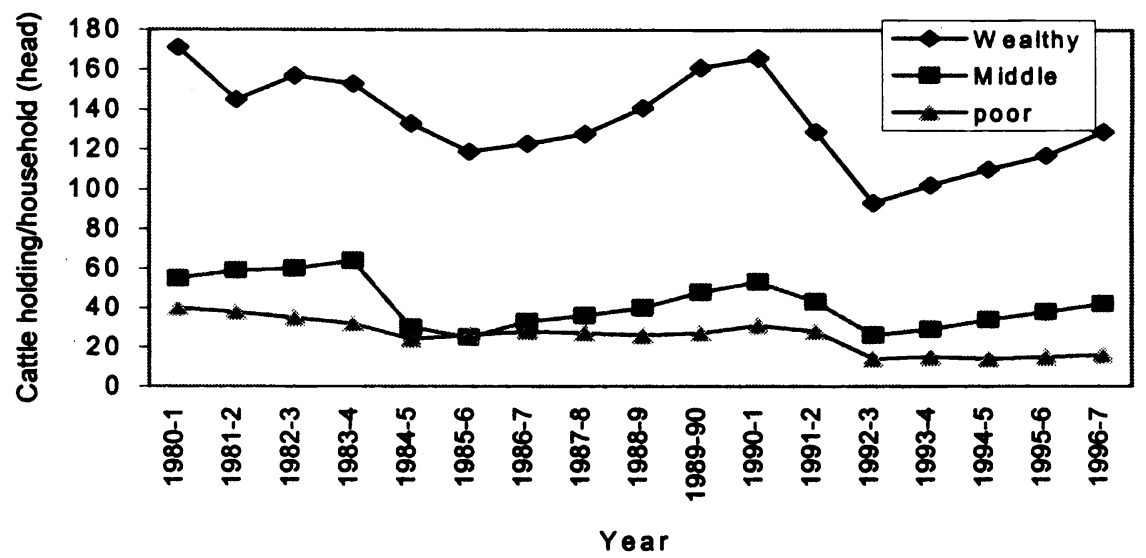

Fig. 3. Cattle population dynamics aggregated for wealthy, middle class, and poor economic classes of Borana households for the period 1980-97. Economic classes corresponded to variation in ratios of cattle to people. Source: Desta (1999).

rainfall and stocking rate, however, the interaction was never significant.

Results from the statistical analysis of factors associated with the magnitude (percent) of cattle mortality-given mortality occurred-are shown in Table 3. These results indicate that increased magnitude of mortality was consistently and strongly associated with decreased rainfall. Increased stocking rate was associated with increased magnitude of mortality in only 1 of 8 cases, namely immature catcant in 2 of 8 cases, namely mature cattle at Negelle and immature cattle at Arero. The interactions are depicted in Figure $4(a, b)$. These graphs illustrate that the magnitude of cattle mortality increased as a function of increased stocking rates at lower levels of rainfall. tle at Mega. The interaction was signifi-

Table 1. Current annual change in rainfall, previous years' stocking rate, and current annual change in cattle numbers for 56 pastoral households on the central Borana Plateau for 1982-97.

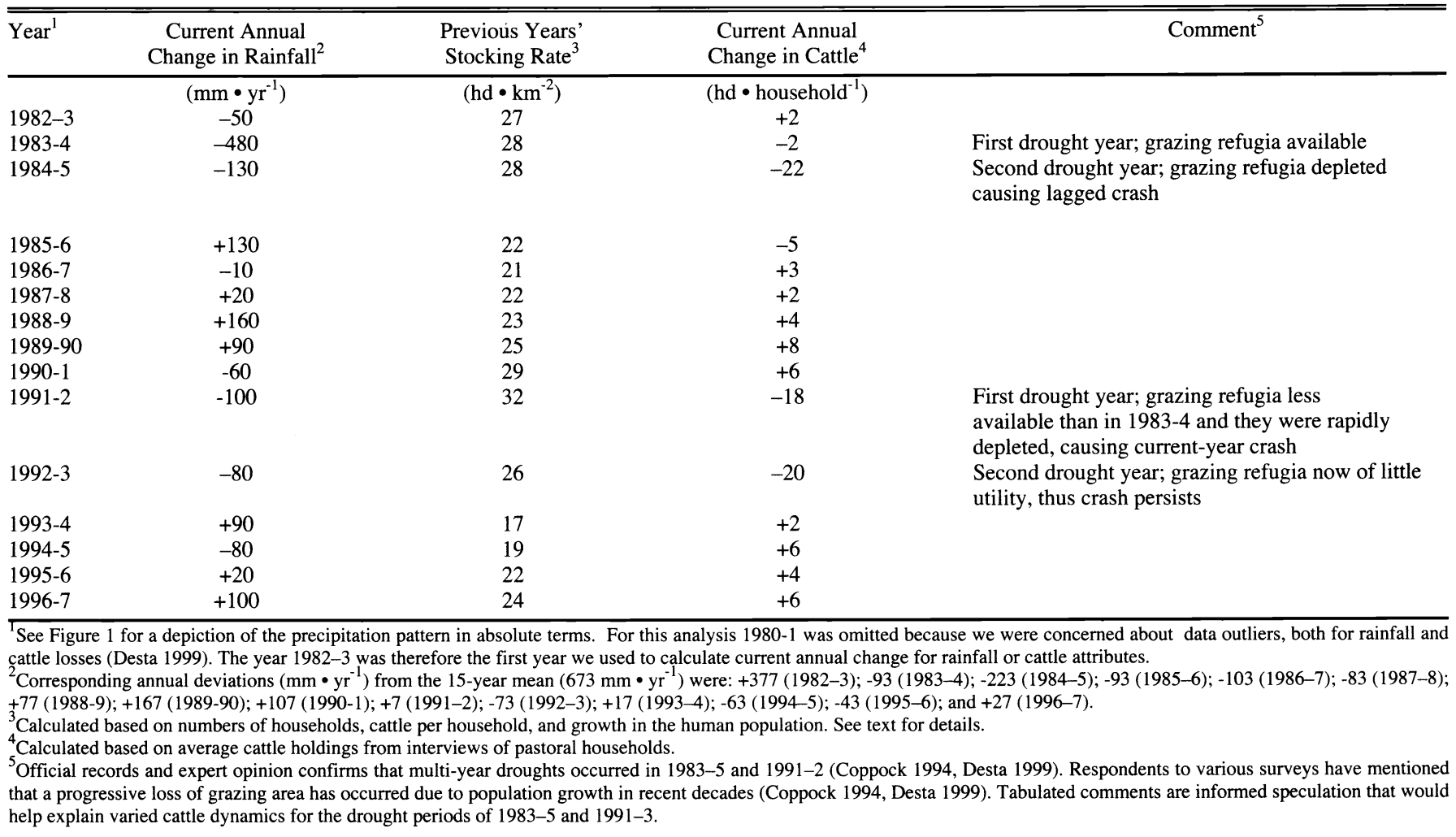




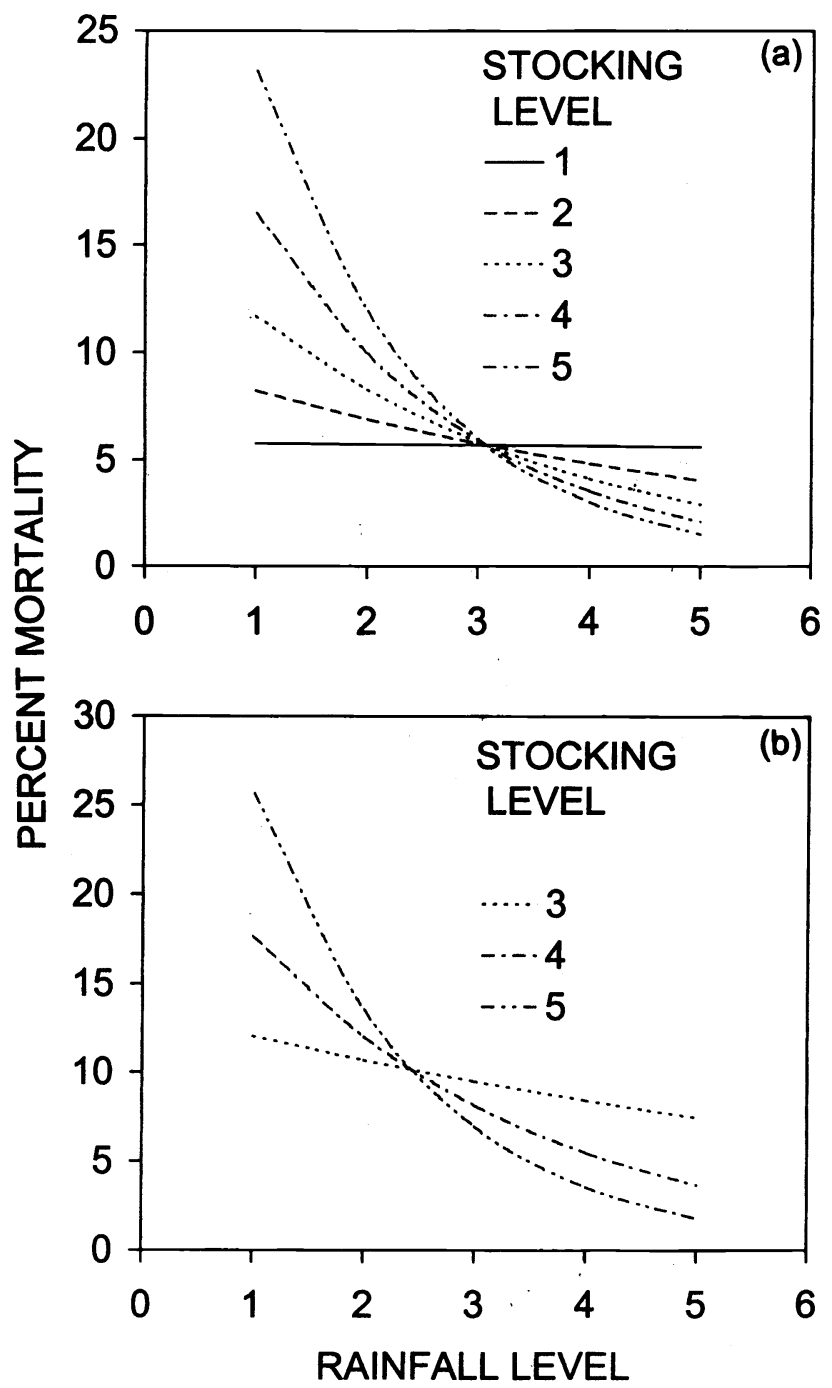

Fig. 4(a,b). Interaction between stocking rate and rainfall for magnitude of mortality for (a) immature cattle at the Arero site and (b) mature cattle at the Negelle site for the period 1980-97. Rainfall and stocking rates were based on recall of respondents from group interviews and were scaled as: 1 (very low), 2 (low), 3 (average), 4 (high), and 5 (very high). Immature cattle were those $<4$ years old while matures were all other cattle. The Negelle site had only 3 stocking rates compared to 5 for Arero. Source: Desta (1999).

\section{Discussion and Conclusions}

Overall, our research has provided useful information and a valid test of theory given the complexity of the pastoral system, the lack of ancillary or validation data, and limitations of our survey methods. The core data set for cattle dynamics is reasonably accurate despite being based on recall. Consistency among respondents in establishing a calendar of events, their intimate knowledge of cattle inventories, and the relatively few sources of change for cattle numbers reduced the scope for accounting errors.
Some of our statistical analyses yielded puzzling results, but we believe these can be reconciled. We better recognize why complex system dynamics can be poorly suited for conventional statistical analysis. Scoones (1993) also noted the difficulties when attempting to precisely identify regulatory factors affecting "real-world" populations. In the following discussion, therefore, we concentrate more on the simplest descriptive evidence to build a case that equilibrial controls - embodied by periodic interactions between rainfall and stocking rate-predominate in this semiarid system.

\section{Regional Cattle Dynamics}

Results from our statistical analysis at the regional scale were indeed paradoxical-they indicated that neither annual change in rainfall or the previous years' stocking rate significantly affected current annual change in cattle numbers. While we believe the data sets used in the regional analysis are valid, we strongly assert that the statistical implications are easily misinterpreted. The problem likely occurred because we omitted an essential third factor from the analysis - a loss of grazing refugia between 1984 and 1991that reduced carrying capacity and increased herd instability in response to rainfall deficits. This altered the quantitative relationships among rainfall deficits, stocking rates, and cattle mortality to an extent that successive drought events were not statistical replicates, even though the overall magnitude of cattle mortality was similar for each case. We thus focus the remainder of this discussion on the basic pattern of regional herd dynamics along with annual rainfall data because they alone are very revealing.

The strongest evidence that cattle numbers on the Borana Plateau are primarily governed by stocking-rate factors is the overall boom-and-bust pattern for regional herd dynamics. We interpret the gradual growth of the regional herd over 6 years from 1985 to 1990 , and over 4 years from 1993 to 1997 , as evidence that the population attempts to track a carrying capacity. Cattle numbers indeed collapse in response to a rainfall deficit, but the system is primed for catastrophe by population size. If cattle dynamics were nonequilibrial and thus rainfall-driven, we should have observed a far more erratic or volatile pattern (Ellis and Swift 1988, Ellis et al 1993).

Our time-series data are now augmented by other observations from the late 1990s that add credence to the idea that herd crashes are becoming a more regular-and hence a more predictable - feature of this production system. Shibru (unpubl., 2001) reported another population crash on the central Borana Plateau during 1998-9 that claimed $62 \%$ of the cattle population. His findings were based on 2 distinct surveys of 89 and 137 pastoral households. The rainfall for 1998-9 was $318 \mathrm{~mm}$ (Shibru, unpubl.), or about half of a 17-year mean of $637 \mathrm{~mm}$ (Desta 1999). The crash of 1998-9 was the culmination of another 5 years of herd growth that started in 1993. 
Table 2. Associations of annual rainfall (RF), stocking rate (SR), and interaction between rainfall and stocking rate (RF $x$ SR) with occurrence of cattle mortality (i.e. probability of mortality $\operatorname{Pr}(M))$ during 1980-97 from values reported by 56 Borana households across 4 study sites in southern Ethiopia ${ }^{1}$.

\begin{tabular}{lcccccc}
\hline \hline & \multicolumn{7}{c}{ Age Class of Cattle } \\
\cline { 2 - 7 } & \multicolumn{7}{c}{ Mature } & Immature \\
\cline { 2 - 7 } Study site & RF & SR & RF x SR & RF & SR & RF x SR \\
\hline Yabello & $* *$ & $* *$ & NS & $* *$ & $* *$ & NS \\
Mega & $* * *$ & NS & NS & $* * *$ & $*$ & NS \\
Arero & $* *$ & $* *$ & NS & $* * *$ & $*$ & NS \\
Negelle & $*$ & NS & NS & $* * *$ & $*$ & NS \\
\hline
\end{tabular}

$*, * *, * * *$ Significant at $0.05,0.01$, and 0.001 levels, respectively.

${ }^{1}$ Based on multiple logistic regression of mortality occurrence in a doubly repeated measures design (Desta 1999). For example, the regression equation for Yabello mature cattle is:

$$
\operatorname{Pr}(M)=\exp (\mathrm{g}(\underline{\mathrm{x}})) /(1+\exp (\mathrm{g}(\underline{\mathrm{x}}))) \text {, where } \mathrm{g}(\underline{\mathrm{x}})=0.893-(0.716 \bullet \mathrm{RF})+(0.264 \mathrm{x} \text { SR })-(0.093 \mathrm{x} \mathrm{RF} \times \mathrm{SR}) .
$$

${ }^{2}$ Immatures were $<4$ years old and matures were all other cattle. The degrees of freedom were as follow: Yabello matures (175), Mega matures (173), Arero matures (181), Negelle matures (190), Yabello immatures (175), Mega immatures (173), Arero immatures (181), and Negelle immatures (190).

Based on our data and that of Shibru (unpubl., 2001), we postulate that the interval of 5 to 6 years between crashes is primarily determined by the time required for the regional cattle herd to grow and reach a density at which grazing resources become heavily utilized - this is when the regional herd becomes vulnerable to sudden deficits in forage supply. The rapid growth potential for cattle numbers is encouraged by the relatively favorable production environment (see Study Area). Although a declining carrying capacity has been postulated, and this makes estimation of critical thresholds problematic, we would speculate that vulnerability of the regional herd to forage deficits markedly increases when cattle numbers exceed on the order of $20 \mathrm{head} / \mathrm{km}^{2}$, or 310,000 head for our study region. Once the population has exceeded a critical density, sudden feed shortages - and high rates of cattle

Table 3. Associations of annual rainfall (RF), stocking rate (SR), and interaction between rainfall and stocking rate (RF $x$ SR) with percent cattle mortality during 1980-97 from values reported by 56 Borana households across 4 study sites in southern Ethiopia. These analyses examined the magnitude of mortality given that mortality occurred; zero mortality values were omitted.

\begin{tabular}{lcccccc}
\hline \hline & \multicolumn{7}{c}{ Age Class of Cattle ${ }^{2}$} \\
\cline { 2 - 7 } Study site & RF & SR & RF x SR & RF & SR & RF x SR \\
\cline { 2 - 7 } Yabello & $* * *$ & NS & NS & $* * *$ & NS & NS \\
Mega & $* * *$ & NS & NS & $* *$ & $* * *$ & NS \\
Arero & $* *$ & NS & NS & $* * *$ & NS & $*$ \\
Negelle & $* * *$ & NS & $* *$ & $* * *$ & NS & NS \\
\hline
\end{tabular}

*.**.***Significant at $0.05,0.01$, and 0.001 levels, respectively.

${ }^{1}$ Based on weighted multiple linear regression of the transformed (log-arcsine-square root) percent mortality in a doubly repeated measures design (Desta 1999), with total herd sizes as weights. For example, the regression equation for Yabello immature cattle is:

Percent mortality $=100 \% \mathrm{x}(\sin (\exp (\mathrm{h}(\mathrm{x}))))^{2}$, where $\mathrm{h}(\underline{\mathrm{x}})=-0.576-(0.251 \times \mathrm{RF})-(0.0306 \times \mathrm{SR})+(0.0106 \times \mathrm{RF} \times$ $\mathrm{SR})$.

${ }^{2}$ Immatures were $<4$ years old and matures were all other cattle. The degrees of freedom were as follow: Yabello matures (100), Mega matures (47), Arero matures (47), Negelle matures (82), Yabello immatures (87), Mega immatures (38), Arero immatures (44), and Negelle immatures (54). more strongly related to both rainfall deficits and high stocking rates. We posit that the magnitude of each crash is defined by the size of the rainfall deficit in relation to the stocking rate in the "trigger year." We hypothesize that the higher the stocking rate and lower the rainfall, the larger the crash.

Perhaps an even more direct illustration of the important role of stocking rate in cattle crashes is the observation that not every "dry" year in the 17 covered by our research produced a crash. For example, the years 1986-8, 1992, and 1994 had rainfall on the order of 580-600 mm per annum-typically as "dry" or "drier" than most years that produced crashes - but cattle mortality was very low at these times. We surmise that the reason mortality was low in these years was because stocking rates were low. Stocking rates were low because herds were at reduced numbers during periods of herd recovery following previous crashes.

Recent reconnaissance on the Borana Plateau provides more information that helps complete a picture for cattle dynamics at the regional scale (S. Desta, pers. obs.). The long rains appear to be considerably above average by mid-2001, with one result being some of the largest standing crops of forage in recent memory. The regional cattle herd still appears small in number, however, as it is still recovering from the crash of 1998-9. Given this scenario, we expect the next regional cattle crash will be most likely to occur by 2005 . The pastoral population thus finds itself in a "vicious cycle."

\section{Local Cattle Mortality Perceptions of Rainfall and Stocking Rate}

The statistical results for the associations of stocking rate and rainfall with cattle mortality at the local scale produced some results that were equivocal compared to our interpretation of factors affecting cattle dynamics at a regional scale. The statistical results suggest that main effects of stocking rate, and interactions between stocking rate and rainfall, were relatively minor compared to the main effect of rainfall. This was especially the case for the magnitude of cattle mortality, which is the main response variable of interest when examining possible density-dependent interactions.

We must be particularly cautious, however, about making detailed interpretations 
of these results. This is primarily because we are concerned that selective memories of respondents could introduce differential degrees of accuracy, especially with respect to the scaling of rainfall or stocking rate. Our correlation analysis indicated little agreement between perceived versus actual rainfall, but we concede that local rainfall may have substantially varied from that measured at climate stations located at higher elevations, often many kilometers away. The people were able to reliably identify years of drought and crisis, and deserve credit for that. Our concern, however, is more related to our speculation that drought years could be remembered in more vivid terms than years of higher stocking rates. Although we offer no proof, we suspect that stocking rate could be harder to accurately scale from memory compared to rainfall. This problem could be compounded by pastoral management practices that attempt to mitigate high stocking rates through herd dispersal during periods of crisis. For example, during droughts cattle can be rapidly moved from local warra sites to distant forra locations to reduce stocking rates near homesteads and help conserve local forage and water resources (Coppock 1994, Desta 1999). Such herding practices could make it more difficult for respondents to accurately gauge stocking rates during stress years.

If we assume, however, that these results have a reasonable degree of accuracy, and accept the idea that the association of cattle mortality with rainfall deficits is probably biased to some degree by more vivid recollections of respondents compared to those concerning stocking rate, several issues merit exploratory comment. First is site variability. Although all aspects of cattle mortality were strongly associated with decreasing rainfall regardless of site, site variation did occur with respect to influences on mortality associated with an increasing stocking rate, either in isolation from, or with respect to, interactions with rainfall. This site variation makes sense in light of potential differences in resource endowments and the degree to which each site is bounded or flanked by potentially competitive neighbors (see Study Area and Sampling). Based on such criteria, we could expect, for example, that cattle in the Negelle site could exhibit the lowest degree of densitydependent interactions compared to those in Arero, Mega, and Yabello. No such pattern emerged, however, either for occur- rence or magnitude of mortality. Thus we lack an explanation as to how influences of stocking rate could vary by site. The second issue concerns potential variation in factors affecting mortality for mature versus immature cattle. We could expect, for example, that compared to mature cattle, mortality of immatures would be more influenced by stocking rate. This is because immatures are often kept close to homesteads in "sacrifice zones" during stress periods and thus potentially subjected to acute resource restrictions (Coppock 1994). The observed pattern for occurrence of mortality gives some support to this contention, but this is not the case for magnitude of mortality. Both issues of mortality variation due to site and age class of cattle thus remain muddled. A comprehensive, site-specific study of resource and management dynamics would be required to clarify hypotheses.

\section{Synthesis of Cattle Dynamics}

The most cautious, and thus most appropriate, conclusion from our work is that both equilibrial (stocking rate) and nonequilibrial (rainfall) factors influence cattle dynamics on the Borana Plateau. Our conclusion echoes to some extent work by Scoones (1993). He found that cattle populations over a 63-year period in communal areas of semi-arid Zimbabwe tended to be regulated by density-dependent factors acting on birth and death rates during "normal" years, but that numbers were also periodically limited by density-independent factors such as drought.

It is obvious, as in other pastoral systems, that livestock numbers and animal productivity vary from year to year on the Borana Plateau. While some may interpret any deviation from static conditions as evidence of non-equilibrium dynamics (Sidahmed 1993), the defining process for an equilibrial system is density-induced, negative feedback (Berryman 1989). Equilibrium conditions therefore exist as long as a population oscillates around some mean, regardless of the amplitude. Hence, a highly variable system can still be an equilibrial system. Indeed, making allowance for a likely downward trend in carrying capacity and inevitable noise in the data, the boom-and-bust pattern for cattle numbers in southern Ethiopia almost resembles a limit cycle, indicative of a prevailing influence of stocking-rate over herd dynamics. Although rainfall deficits can indeed trigger calamitous cattle losses here, we contend that effects of rainfall deficits are magnified or mitigated by stocking level.

Despite having put our foot more firmly in the equilibrial camp for southern Ethiopia, we have little problem believing that hot, very arid systems such as that in South Turkana, Kenya, can have livestock dynamics largely driven by climate variability (Ellis and Swift 1988). Turkana cattle, in particular, depend on a highly unstable herbaceous layer dominated by annual grasses and forbs. When the long rains fail in South Turkana, there can be no herbaceous cover on the sandy plains or lava hills, regardless of animal numbers. Then animals must trek to grazing refugia in steep montane regions or noman's lands between ethnic territories, often at great peril to herders and stock (Coppock et al. 1986a).

We also realize that the reliance on livestock numbers as our main response variable was a conservative choice. Had we been able to focus on milk production, for example, a higher degree of climate effect could have been observed given the role that rainfall events play in greening-up forage, improving livestock nutrition, and spurring lactation (Coppock et al. 1986a, 1986b). Mortality in particular was logical for us, however, given our reliance on recall information and a focus on household capital assets.

Our research at least indirectly points to the importance of key resources in understanding pastoral system dynamics. Illius and O'Connor (1999) contended that animal numbers in African pastoral systems are regulated in a density-dependent fashion by limited forage in key resource areas. They noted that strong equilibrial forces thus occur over a limited part of pastoral systems, and effects elsewhere are more heterogeneous. Our experience offers some support for this concept. More study of key resources is required, however, to clearly confirm that loss of grazing refugia is contributing to system instability in southern Ethiopia.

Our results also suggest that when characterizing patterns of cattle dynamics, and hence making interpretations about equilibrial or non-equilibrial influences on population processes, scale of resolution matters. For example, at a local scale we have ample evidence that households can vary in the degree that their herds are affected by calamity - some may be wiped out while others suffer relatively little (Desta 1999). Such differences could be 
related to pure luck and/or variability in management skills, access to social reciprocity networks, resource dynamics, local precipitation, etc. Potentially erratic or volatile patterns of local herd dynamics could appear to be driven by density-independent factors. At a regional scale, however, we would speculate that a smoothing effect emerges as a result of aggregating many local outcomes. This aggregated pattern serves to dampen volatility and therefore appears to reflect more densitydependent influences. The simplest explanation for effects of scale would be a "zero-sum" nature of cumulative grazing interactions. For example, animals that die at one locale can create a potential pocket of surplus resources accessible to animals from elsewhere. Such reciprocity in resource use is inherent in the traditional madda system (see Study Area).

\section{Comments on Vegetation Change}

Vegetation analysis per se was not part of this particular research project, but some comments are warranted-in the context of non-equilibrium conceptswith regards to previous work on vegetation change that has been conducted on the Borana Plateau. Both plants and animals should be considered in a comprehensive examination of theory.

In a climate-driven system, vegetation dynamics should be primarily driven by factors such as moisture variability rather than herbivory (Ellis and Swift 1988). It has been found that vegetation in arid environments tends to exhibit more nonequilibrial features, while vegetation in mesic environments is more subject to equilibrial influences (see review in Illius and O'Connor 1999, Fernandez-Gimenez and Allan-Diaz 1999).

The issue of what controls vegetation change is particularly important for pastoral systems in developing countries because erroneous assumptions can lead to inappropriate policy and hence, even more problems for people. For example, in a non-equilibrial setting, pastoralists could inordinately suffer in economic terms from forced de-stocking to reduce damage from overgrazing, when in fact climate is driving negative trend in resource condition (Ellis and Swift 1988, Scoones 1993). The converse, however, is also a problem; namely, assuming that a negative trend in resource condition is attributable to climate and thus absolving land users of their responsibilities for stewardship (Illius and O’Connor 1999).
The best available empirical information for the Borana Plateau indicates that bush encroachment and erosion of surface soils has widely occurred over the past few decades, particularly at higher elevations in upper semi-arid and sub-humid locations (Billé 1985, Coppock 1993, 1994). Proliferation of woody plants has occurred at both local and regional scales; this distinction is important because regionalscale change can be more attributable to climate effects, while local-scale change can be more attributable to management or utilization practices (Mortimore 1989; Stafford-Smith and Pickup 1993; Fairhead and Leach 1996). Bush encroachment on the Borana Plateau is proposed to occur in response to heavy grazing and lack of fire. Lack of fire is related to a grazing-related reduction in herbaceous fuel and policy that has banned burning since the mid-1970s (see Study Area). The heavy grazing pressure is thought to have arisen as a result of increased sedentarization of pastoralists and their herds. This has resulted from several factors including development of permanent ponds, a steady increase in human and livestock populations, and the increasing allure of towns and markets. We therefore believe that livestock (cattle) are also a source of substantial vegetation change in many parts of the Borana Plateau. This reinforces our contention that we are dealing with a dynamic and multi-faceted equilibrial system.

\section{Development Implications}

We contend that pro-active management has a much greater role to play in dynamic equilibrial systems compared to that for non-equilibrial systems. If herd crashesand hence massive losses of capital assets - are mediated by stocking rate, then stocking rate could serve as a fairly reliable early warning tool to promote hedging behavior for pastoral risk management. One idea, given an increasing likelihood that households will regularly suffer from herd depletion, is to promote more-timely sales of less-productive animals before crises occur, and direct these revenues into sustainable development schemes that encourage forms of economic diversification that complement traditional livelihoods. We remain firm in our prediction that another cattle crash is most likely to occur on the Borana Plateau by 2005. This gives pastoralists and development agents a timeline to implement riskmanagement interventions that could better buffer the local population.
There is an important distinction between advocating some timely de-stocking to promote a measure of herd stability and economic development, versus the time-worn (and usually failed) approach of official coercion to de-stock in the name of environmental protection - the latter has been often attempted elsewhere in Africa. We suspect the former approach would be far more fruitful with people like the Boran who are increasingly living on the margins of social and economic security. They are looking for new options to augment their livelihoods (Desta 1999).

Cattle mortality represents a significant economic loss to Borana society. The average annual loss of USD 384 per household is nearly 3-times the average annual cash income of USD 135 (Coppock 1994). To illustrate further, if our results are extrapolated to the entire Borana Plateau where drought impacts have been similar, the loss of livestock wealth could exceed USD 300 million since 1980. If pastoral systems from northern Kenya are included over the same time frame, combined losses for cattle alone could exceed USD 750 million, while adding losses of small ruminants and camels could make grand total losses over USD 1 billion (P. Little, pers. comm.). Capturing even a fraction of such losses could be a useful start. The approach could include creating a virtuous cycle involving improved marketing, enhanced rural finance, viable alternative investments, and ultimately economic diversification (Desta et al. 1999).

Efforts to regain some measure of system stability in response to drought could also involve rehabilitation and management of key resources and thus restoration of traditional mobility patterns. This would help communities to again be able to respond to crisis in adaptive, traditional ways. Community investment that prioritizes relocation of people who now reside in former (unoccupied) grazing refugia could be an important first step in this process.

Finally, we urge that more researchers broaden their attention from detailed analyses of plant and animal population dynamics to include human population dynamics in pastoral systems. This and other work conducted in southern Ethiopia points to human population growth as a critical variable that explains much of the change in resource use and one that can illuminate new windows of opportunity for development intervention. 


\section{Literature Cited}

Afifi, A.A. and V. Clark. 1990. Computeraided multivariate analysis ( $2^{\text {nd }}$ Ed.). Chapman and Hall, New York, N.Y.

Assefa, M. 1990. Borana cattle herds: Productivity, constraints, and possible interventions. Master's thesis, Colorado State Univ., Fort Collins, Colo.

Behnke, R. H. and I. Scoones. 1993. Rethinking range ecology: Implications for range management in Africa, p. 1-30. In: Behnke, R.H., I. Scoones, and C. Kerven (eds.). Range ecology at disequilibrium: New models of natural variability and pastoral adaptation in African savannas. Overseas Dev. Institute, London, U.K.

Berryman, A. A. 1989. The conceptual foundations of ecological dynamics. Bull. Ecol. Soc. Amer. 70:230-236.

Billé, J.C. 1985. Some aspects of bush encroachment in the African rangelands, $p$. 213-216. In: Tothill, J.C., and J.J. Mott (eds.). Ecology and management of the world's savannas. Australian Acad. of Sci., Canberra, Australia.

Caughley, G. 1979. What is this thing called carrying capacity?, p. 2-8. In: Boyce, M.S., and L.D. Hayden-Wing (eds). North American elk: Ecology, behavior and management. University of Wyoming Press, Laramie, Wyo.

Coppock, D.L. 1993. Vegetation and pastoral dynamics in the southern Ethiopian rangelands: Implications for theory and management, p. 42-61 In: Behnke, R.H., I. Scoones, and C. Kerven (eds.). Range ecology at disequilibrium: New models of natural variability and pastoral adaptation in African savannas. Overseas Dev. Institute., London, U.K.

Coppock, D.L. 1994. The Borana plateau of southern Ethiopia: Synthesis of pastoral research, development and change, 1980-91. Systems study No. 5. Internat. Livestock Center for Africa, Addis Ababa, Ethiopia.

Coppock, D.L., J.E. Ellis, and DM Swift. 1986a. Livestock feeding ecology and resource utilization in a nomadic pastoral ecosystem. J. Appl. Ecol. 23(2):573-584.

Coppock, D.L., D.M. Swift, and J.E. Ellis. 1986b. Seasonal nutritional characteristics of livestock diets in a nomadic pastoral ecosystem. J. Appl. Ecol. 23(2):585-596.

Cossins, N.J. and M. Upton. 1987. The Borana pastoral system of southern Ethiopia. Agr. Systems 25:199-218.

CSA (Central Statistical Authority). 1996. The 1994 Population and housing census of Ethiopia: Results for Oromiya Region. Vol. I, Part I: Statistical report on population size and characteristics. Central Statistical Authority. Addis Ababa, Ethiopia.

Desta, S. 1999. Diversification of livestock assets for risk management in the Borana pastoral system of southern Ethiopia. Ph.D. Diss., Utah State Univ., Logan, Ut.
Desta, S., D.L. Coppock, and C. Barrett. 1999. Opportunities for asset diversification in a livestock system: The case of the pastoral Boran of southern Ethiopia, p. 35-6. In: Eldridge, D., and D. Fruedenberger (eds.). Proceedings of the $\mathrm{VI}^{\text {th }}$ Internat. Rangelands Congress, volume 1. VIth Internat. Rangeland Congress, Inc. Townsville, Queensland, Australia.

Dodd, J.L. 1994. Desertification and degradation in sub-Saharan Africa - the role of livestock. BioSci. 44(1):28-34.

Ellis, J.E. and D.M. Swift. 1988. Stability of African pastoral ecosystems: Alternate paradigms and implications for development. J. Range Manage. 41: 450-459.

Ellis, J.E., M.B. Coughenour, and D.M. Swift. 1993. Climate variability, ecosystem stability, and the implications for range and livestock development, p. 31-41. In: Behnke, R.H., I. Scoones, and C. Kerven (eds.). Range ecology at disequilibrium: New models of natural variability and pastoral adaptation in African savannas. Overseas Development Institute, London, U.K.

Ensminger, J. 1992. Making a market: The institutional transformation of an African society. Cambridge Univ. Press, Cambridge, U.K.

Fairhead J. and M. Leach. 1996. Rethinking the forest-savanna mosaic: Colonial science \& its relics in west Africa, p. 105-121. In: Leach, M., and R. Mearns (eds.). The lie of the land: Challenging received wisdom on the African environment. The International African Institute, James Curry Ltd., Oxford, U.K., and Heineman, Portsmouth, N.H, U.S.A.

Fernandez-Gimenez, M.E. and B. AllenDiaz. 1999. Testing a non-equilibrium model of rangeland vegetation dynamics in Mongolia. J. Appl. Ecol. 36:871-885.

Homewood, K., and J. Lewis. 1987. Impact of drought on pastoral livestock in Baringo, Kenya, 1983-85. J. Appl. Ecol. 24:617-631.

Illius, A. W., and T.G. O'Connor. 1999. On the relevance of nonequilibrium concepts to arid and semiarid grazing systems. Ecol. Appl. 9(3):798-813.

Lamprey, H.F. 1983. Pastoralism yesterday and today: the overgrazing problem. $\mathrm{p}$. 643-666. In: F. Bourliere (ed.). Tropical savannas: Ecosystems of the world, Vol. 13. Elsevier, Amsterdam, the Netherlands.

Legesse, A. 1973. Gada: Three approaches to the study of African society. The Free Press, New York, N.Y.

Littell, R.C., G.A. Milliken, W.W. Stroup, and R.D. Wolfinger. 1996. SAS ${ }^{\circledR}$ system for mixed models. SAS Institute, Inc., Cary, N.C..

Meadows, S.J. and J.M. White. 1979. Structure of the herd and determinants of offtake rates in Kajiado District in Kenya 1962-77. Paper 11e of the Pastoral Development Network. Overseas Development Institute, London, U.K.
Mortimore, M. 1989. Adapting to drought: Farmers, famines and desertification in West Africa. Cambridge Univ. Press, Cambridge, U.K

SAS (Statistical Analysis System) Institute, Inc. 1996. SAS/STAT ${ }^{\circledR}$ software: Changes and enhancements through release 6.12. SAS Institute Inc., Cary, N.C.

Scoones, I. 1993. Why are there so many animals? Cattle population dynamics in the communal areas of Zimbabwe, p. 62-76 In: Behnke, R.H., I. Scoones, and C. Kerven (eds.). Range ecology at disequilibrium: New models of natural variability and pastoral adaptation in African savannas. Overseas Development Institute, London, U.K.

Shibru, M. 2001. Pastoralism and cattle marketing: A case study of the Borana of southern Ethiopia. Master's thesis, Egerton Univ., Njoro, Kenya.

Sidahmed, A. 1993. Viewpoint: Do we need new terminologies in rangeland management? Rangelands 15(2):81.

Stafford-Smith M. and G. Pickup. 1993. Out of Africa, looking in: Understanding vegetation change, p. 196-248. In: Behnke, R.H., I. Scoones, and C. Kerven (eds.). Range ecology at disequilibrium: New models of natural variability and pastoral adaptation in African savannas. Overseas Development Institute, London, U.K. 